\title{
MODALITAS GANDA DALAM BAHASA INGGRIS DAN PADANANNYA DALAM BAHASA INDONESIA: KAJIAN SINTAKSIS DAN SEMANTIK
}

\author{
Deden Novan Setiawan Nugraha ${ }^{1}$, Fitriani Reyta ${ }^{2}$ \\ ${ }^{I}$ Fakultas Bisnis dan Manajemen, Universitas Widyatama \\ Email: deden.novan@widyatama.ac.id \\ ${ }^{2}$ Fakultas Bisnis dan Manajemen, Universitas Widyatama \\ Email:fitriani.reyta@widyatama.ac.id
}

\begin{abstract}
ABSTRAK
Bahasa memiliki fungsi utama sebagai alat komunikasi. Setiap bahasa memiliki keunikan tersendiri serta memiliki aturan agar pemakai bahasa dapat menggunakan bahasa secara baik dan benar dalam berkomunikasi. Bahasa Inggris dan bahasa Indonesia memiliki keunikan tersendiri salah satunya mengenai modalitas. Modalitas merupakan sikap pembicara atas keterlibatannya terhadap kebenaran proposisi tuturannya. Sikap ini bisa dimarkahi dengan pemarkah leksikal yang berbeda yaitu dalam bentuk kata, frasa, atau klausa. Modalitas ada dalam tataran semantik yang berarti dapat muncul dalam semua bahasa dengan bentuk pengungkapnya masing masing. Dengan menggunakan metode deskriptif, penelitian ini mendeskripsikan modalitas ganda dalam bahasa Inggris dan padanannya dalam bahasa Indonesia. Secara sintaksis, bentuk modalitas ganda yang digunakan dalam penelitian ini yaitu verba bantu modal have to dikombinasikan dengan adverb (kata keterangan). Data penelitian ini diambil dari korpus linguistik bernama COCA (Corpus of Contemporary American English). Secara semantik, hasil penelitian menunjukkan terdapat kombinasi antara verba bantu modal yaitu have to dan modal leksikal berupa kata keterangan yaitu surely, certainly yang merupakan pengungkap kesimpulan logis (logical necessity) dan termasuk ke dalam modalitas epistemik yang memiliki makna kepastian yang subjektif. Pengungkapan modalitas epistemik ditunjukkan oleh pemunculan kepastian penutur yang melibatkan pengetahuannya atau keyakinannnya. Dalam hal ini terlihat bahwa penutur telah menarik suatu kesimpulan dari hal-hal yang telah diketahui atau diamati sebelumnya. Padanan have to dalam bahasa Indonesia menjadi 'seharusnya' dan termasuk ke dalam pengungkap ekstraklausal, dimana terdapat kecenderungan penutur untuk menyatakan bahwa keharusan yang diungkapkan tersebut berasal dari dirinya sendiri, bukan dari orang lain.
\end{abstract}

Kata Kunci: Modalitas Ganda, Sintaksis, Semantik

\begin{abstract}
The main function of a language is as a communication tool. Each language is unique and governed by rules for language speakers to use the language properly and correctly in communicating. English and Indonesian are unique in the sense of modality. The modality is the speaker's attitude towards his/her involvement in the truth of his/her speech proposition. This attitude can be marked by different lexical markers in the form of words, phrases or clauses. Modality exists on semantic level which means that it can appear in all languages with their respective expressions. Using descriptive method, this study describes dual modalities in English and their equivalents in Indonesian. Syntactically, the form of double modality used in this study is the "have to" combined with adverbs. The research data was taken from a linguistic corpus called COCA (Corpus of Contemporary American English). Semantically, the result of the study shows a combination between modal auxiliary verb "have to" and lexical modal in the form of adverbs "surely", "certainly" which are expressions of logical necessity belonging to epistemic modality with subjective meaning of certainty. Disclosure of epistemic modality is demonstrated by the appearance of the certainty of the speaker who involves his/her knowledge or beliefs. In this case it appears that the speaker has drawn a conclusion from the things previously known or observed. The equivalent to "have to" in Indonesian is "seharusnya" and is included in extraclausal disclosures, where there is a tendency for the speaker to state that the expressed obligation originates from him/herself and not from others.
\end{abstract}

Keywords: Multiple Modalities, Syntax, Semantics 


\section{PENDAHULUAN \\ Latar Belakang}

Bahasa merupakan alat komunikasi yang penting dalam kehidupan sosial. Selain sebagai alat komunikasi, bahasa berfungsi pula sebagai alat ekspresi yang dapat mengungkapkan pikiran, dan perasaan. Dalam berbagai literatur dan studi-studi perbandingan antarbahasa, banyak ditemui persamaan sekaligus perbedaan dalam bahasa-bahasa yang menjadi objek kajian studi. Bahasabahasa di dunia memiliki persamaan yang bersifat universal yang lazim disebut dengan kesemestaan bahasa (Keraf, 1982:167). Dalam bidang fonologi, persamaan antarbahasa di dunia dapat dilihat dari kenyataan bahwa semua bahasa memiliki vokal. Dari segi morfologi terdapat kesamaan konsep dasar yang konkret di mana setiap bahasa memiliki kata-kata dasar atau unsur akar kata. Persamaan dapat juga dilihat dari adanya kategori verba (V), nomina (N), frasa nominal, subjek, dan objek pada setiap bahasa.

Dalam perkembangannya, bahasa sebagai media komunikasi telah mengalami kemajuan yang cukup pesat seiring berkembangnya ilmu pengetahuan dan teknologi di belahan dunia termasuk pula di Indonesia. Hal ini ditandai dengan banyaknya publikasi di Indonesia yang ditulis dalam bahasa asing, terutama dalam bahasa Inggris. Oleh karena itu, bangsa Indonesia yang mengikuti perkembangan ilmu pengetahuan dan teknologi, setidaknya dapat menguasai bahasa khususnya bahasa Inggris terlebih bahasa Indonesia yang merupakan bahasa nasional.

Bahasa Inggris dan bahasa Indonesia secara historis merupakan dua bahasa yang berasal dari rumpun yang berbeda dan keduanya memiliki keragaman serta kekhasan yang menarik untuk diteliti lebih luas dan dikaji secara lebih mendalam. Kekhasan suatu bahasa terasa jika suatu kata, ungkapan atau kalimat dapat dicari padanannya dalam bahasa lain. Dalam hal pemadanan antar bahasa, pikiran akan tertuju pada terjemahan sebuah teks dari suatu bahasa ke bahasa lain yang melibatkan peralihan baik bentuk bahasa maupun makna. Dengan kata lain, bukan hanya bahasa sumber yang diganti dengan bentuk bahasa sasaran tetapi juga dilakukan peralihan makna dari bahasa sumber ke bahasa sasaran, meskipun bentuk berubah namun makna tetap sama.

Salah satu penelaahan bahasa adalah kajian sintaksis. Banyak ahli mengemukakan penjelasan atau batasan-batasan sintaksis ini, salah satunya yang dijelaskan oleh Radford (1999:531) yang menyatakan bahwa sintaksis adalah suatu ilmu yang menelaah pola-pola yang dipergunakan sebagai sarana untuk mernggabungkan kata menjadi frasa, klausa, dan kalimat.

Selain sintaksis, penelaahan bahasa dapat dilakukan melalui kajian semantik, yaitu kajian yang membahas aspek-aspek makna dalam bahasa yang mencakup deskripsi makna kata dan makna kalimat. Kempson (1977:214) mengemukakan bahwa ada tiga cara yang digunakan oleh para ahli bahasa dalam menjelaskan makna dalam bahasa manusia: (1) dengan memberikan defenisi hakikat makna kata, (2) dengan mendefinisikan hakikat makna kalimat dan (3) dengan menjelaskan proses komunikasi. Pada cara pertama, makna kata diambil sebagai konstruksi, makna kalimat dan komunikasi dapat dijelaskan; pada cara kedua, makna kalimat yang diambil sebagai dasar, dengan kata-kata difahami sebagai penyumbang yang sistematik terhadap makna kalimat; dan pada cara yang ketiga, baik makna kalimat maupun makna kata dijelaskan dalam batas-batas penggunaannya pada tindak komunikasi.

Pemakai bahasa akan sangat dipengaruhi oleh situasi pada saat bahasa itu digunakan, baik untuk komunikasi maupun sekedar mengekspresikan diri. Apabila pemakai bahasa telah menggunakan sudut pandang pribadi untuk melihat situasi atau peristiwa yang terjadi, secara tidak langsung, hal itu menyatakan sikap subjektivitas. Dalam studi Linguistik, dikenal dengan modalitas yang 
merupakan suatu bentuk bahasa yang mengacu pada sikap pembicara. Modalitas sifatnya universal dan merupakan kategori semantik fungsional. Bloomfield dalam Alwi (1992:5) mengemukakan bahwa kategori semantik tersebut merupakan salah satu fenomena kesemestaan bahasa (language universals). Modalitas sebagai fenomena kesemestaan bahasa menunjukkan bahwa setiap bahasa memiliki unsur leksikal yang dapat digunakan untuk menggambarkan sikap pembicara terhadap apa yang dikemukakan dalam tuturannya. Modalitas, dikalangan para pakar bahasa masih berkembang pandangan-pandangan yang memberikan kesan kurang jelas tentang konsep modalitas, baik dalam hal teori maupun materi.

Dalam penelitian ini, permasalahan difokuskan pada modalitas ganda, yaitu modalitas dalam bahasa Inggris yang mempunyai kombinasi atau gabungan antara unsur modal leksikal dan unsur gramatikal dalam sebuah kalimat. Huddleston (2002:179) memberikan istilah modal harmoni atau kesesuaian modal. Hal ini merujuk kepada modalitas ganda. Bentuk yang paling umum digunakan yaitu kombinasi antara verba bantu modal (modal auxiliary verbs) dan kata keterangan (adverb). Dilihat dari segi maknanya, kombinasi modal leksikal dan gramatikal mengungkapkan makna modal tunggal.

Penggambaran sikap pembicara lazim disebut dengan istilah 'modus'. Dalam hal ini, Djajasudarma (1997:34) menjelaskan bahwa modus adalah manifestasi bentuk-bentuk pengungkapan yang menyatakan modalitas. Badudu (2003:229) menjelaskan pula bahwa istilah modus berupa kata serapan yang berasal dari bahasa Latin yang diartikan sebagai kategori gramatikal dalam bentuk kata kerja (verba) yang mengungkapkan suasana psikologis perbuatan menurut tafsiran atau sikap pembicara tentang apa yang diucapkannya. Hal yang sama dikemukakan oleh Kridalaksana (2001:139), bahwa modus (mood dan mode) adalah kategori gramatikal dalam bentuk verba yang mengungkapkan suasana psikologis perbuatan menurut tafsiran pembicara atau sikap pembicara terhadap apa yang diucapkannya.

Kajian penelitian ini didasari oleh beberapa alasan. Pertama, bahwa unsur modalitas menarik untuk dibahas karena mengacu pada sikap pembicara dan terdapat pada semua bahasa. Kedua, bentukbentuk pengungkapan modalitas dalam bahasa Inggris mencakup beberapa kelas kata dan juga dapat dalam bentuk-bentuk modal (modal auxiliaries) yang dianggap sebagai special verbs atau kelas kata kerja khusus. Judul Penelitian ini yaitu 'Modalitas Ganda dalam Bahasa Inggris dan Padanannya dalam Bahasa Indonesia: Kajian Sintaksis dan Semantik'. Pembahasan tentang modalitas, meskipun telah banyak dilakukan pada penelitian sebelumnya, namun masih menyisakan celah dan permasalahan yang perlu dikaji lebih mendalam.

\section{TINJAUAN LITERATUR}

\section{Sintaksis}

Sintaksis menurut O’ Grady (1997: 181) menyatakan bahwa sintaksis adalah sistem kaidah dan kategori yang memungkinkan kata-kata dikombinasikan untuk membentuk kalimat. Demikian juga Radford (1999: 1) menyatakan; syntax is concerned with the ways in which words can be combined together to form phrases and sentences. Dari batasan-batasan para linguis di atas, dapat disimpulkan bahwa sintaksis adalah suatu kajian linguistik yang menelaah tentang kata, frasa, klausa, dan kalimat,

\section{Semantik}

Menurut O'Grady (1997: 268) dalam Nugraha (2016: 103), semantics is study of meaning in human language. Jadi, maksud pernyataan O'Grady (1996:268) tersebut bahwa semantik adalah ilmu yang mempelajari tentang makna pada bahasa manusia. Menurut Chaer (1992: 284-285), 
semantik dengan objeknya "makna" berada dalam semua tataran linguistik, yakni; fonologi, morfologi dan sintaksis. Semantik merupakan salah satu komponen tata bahasa, dan makna kalimat sangat ditentukan oleh komponen semantik. Hal ini sesuai dengan yang diungkapkan Djajasudarma (1997: 69) bahwa, hubungan antarproposisi yang terdapat pada kalimat dapat dipertimangkan dari segi gramatika dan segi semantik (hubungan makna dalam setiap proposisinya).

\section{Modalitas}

Pandangan dan tafsiran mengenai modalitas sering berbeda antara ahli yang satu dan yang lain. Menurut Perkins (1983:6) dan Ackrill (1963) dalam Alwi (1992:1), istilah modalitas pertama kali dikemukakan oleh Aristoteles, dengan menggunakan sudut pandang yang didasari oleh logika modal (modal logic), yaitu keperluan (necessity), kemungkinan (possibility), dan ketakmungkinan (impossibility) sebagai permasalahan modalitas.

Maningueneau (1976:112) dalam Alwi (1992:1) menyoroti modalitas tidak hanya dari sudut logika. Menurutnya, selain modalitas pikiran (modalite logique), ada juga modalitas apresiatif (modalite appreciative). Modalitas pikiran ialah sikap pembicara yang menggambarkan, antara lain kebenaran, kebolehjadian, dan kepastian, sedangkan yang menggambarkan perasaan gembira dan sedih diklasifikasikan menjadi modalitas apresiasif.

Hal ini sejalan dengan Bally (1942:3) dalam Alwi (1992:1) yang merumuskan modalitas sebagai sikap pembicara tidak hanya berkaitan dengan penilaian berdasar nalar (judgment intellectual) dan penilaian berdasar rasa (judgment affective), tetapi juga dengan keinginan (volente). Yang dimaksudkan adalah merumuskan modalitas sebagai 'bentuk bahasa yang menggambarkan penilaian berdasar nalar, penilaian berdasar rasa, atau keinginan pembicara sehubungan dengan persepsi atau pengungkapan jiwanya.'

Perkins (1983:6) mendefinisikan modalitas dengan istilah yang lebih singkat "things being otherwise" maksudnya yaitu dalam kehidupan sehari-hari, manusia sering berfikir dan berperilaku seakan-akan segala sesuatu itu berbeda dari keadaan yang sebenarnya. Dengan perkataan lain, dunia nyata yang tengah dihadapi oleh seseorang dikontraskan atau dihubungkan dengan dunia kemungkinan (possible words) lain yang ada pada pikiran orang yang bersangkutan ketika dia menghadapi sesuatu di dunia nyata itu. Hal itu mengakibatkan bahwa sebuah proposisi dapat dianggap benar menurut suatu dunia tertentu (dunia sebenarnya atau dunia kemungkinan) atau salah menurut dunia yang lain. Oleh karena itu, sebuah proposisi akan selalu benar apabila proposisi itu benar menurut segala kemungkinan di dunia lain. Jadi dunia ini pun hanya merupakan salah satu dari sekian banyaknya dunia kemungkinan. Kesimpulannya adalah kalau kita memahami dan menerima bahwa sesuatu itu berlainan menurut ukuran dunia nyata, hal itu berarti bahwa kita memahami dan menerima pula keberadaannya menurut ukuran dunia kemungkinan atau bahkan menurut dunia nyata dalam dimensi waktu yang berlainan dari saat sekarang.

Mengenai sesuatu yang berlainan dari keadaan yang sebenarnya menurut ukuran dunia nyata itu, Perkins menggunakan pandangan Lyons (1977:442-448) dalam Alwi (1992:14-16) mengenai adanya tiga jenis maujud (entity) yang satu dengan yang lainnya secara konseptual berbeda.

a). Maujud jenis pertama

Objek yang secara fisik nyata, yaitu manusia, binatang, dan benda dan dalam keadaan normal keberadaannya dalam ruang tiga dimensi relativ konstan dan tidak terikat oleh waktu. 
b). Maujud jenis kedua

Meliputi peristiwa (events), proses (processes), dan suasana keadaan (states of affairs) yang tidak dapat dikatakan sebagai sesuatu yang ada melainkan sebagai sesuatu yang terjadi atau berlangsung.

c). Maujud jenis ketiga

Proposisi adalah satuan abstraksi yang berada di luar dimensi ruang dan waktu serta merupakan sesuatu yang dapat diukur nilai kebenarannya.

Perkins dalam Alwi (1992) menyimpulkan bahwa yang paling sesuai untuk dijadikan landasan konseptual modalitas adalah maujud jenis kedua dan ketiga, yaitu peristiwa (dalam pengertian yang juga mencakupi proses dan suasana keadaan) dan proposisi.

Uraian di atas menggambarkan bahwa Perkins menempatkan modalitas sebagai dunia kemungkinan sehingga kebermaknaan (significance) peristiwa maupun kebenaran proposisi dapat dilihat, diamati, atau bahkan diukur. Untuk itu, diperlukan adanya perangkat prinsip yang sesuai dengan peristiwa atau proposisi yang dilihat dan diukur itu, yaitu: kaidah penalaran atau kaidah rasional (rational laws), kaidah sosial (social laws), hukum alam (natural laws).

Dengan kaidah rasional berarti seseorang melakukan penilaiannya terhadap sesuatu yang dihadapinya melalui daya nalarnya sendiri. Dengan kaidah sosial, interpretasi seseorang terhadap sesuatu yang dihadapinya itu didasarkan pada ketentuan atau peraturan yang berlaku untuk mengatur perikehidupan manusia. Kaidah sosial itu disebut kewenangan atau sumber deontik (deontic source). Dengan kaidah hukum alam seseorang menilai dan menafsirkan segala sesuatu yang dihadapinya didasarkan pada hubungan antara perikeadaan (circumstances) dan peristiwa yang tidak diaktualisasikan (unactualized events)

Huddleston (2002:173) dalam Nugraha et al. (2018:85) menyatakan bahwa "modality is concerned with the speaker's attitude towards the factuality or actualization of the situation expressed by the rest of the clause". Maksudnya modalitas berkaitan dengan sikap pembicara terhadap faktualisasi atau aktualisasi dari situasi yang diungkapkan oleh sisa dari klausa tersebut.

Secara semantik, jenis makna modalitas yang akan digunakan di dalam penelitian ini berdasarkan teori yang dikemukakan oleh Huddleston (2002:177-179) yang menggunakan istilah yang sama dengan Perkins (1983) dan Palmer (1988:96-97) dalam mengelompokkan jenis makna modalitas dalam bahasa Inggris yang terdiri atas tiga kategori, yaitu modalitas epistemik, modalitas deontik, dan modalitas dinamik.

Huddleston (2002:178) berpandangan bahwa "Epistemic' is derived from Greek for 'knowledge': this kind of modality involves qualifications concerning the speaker's knowledge". Maksudnya 'Epistemik' berasal dari bahasa Yunani yang bermakna 'pengetahuan'. Jenis modalitas ini melibatkan kualifikasi mengenai pengetahuan pembicara. Sejalan dengan Huddlestton, Perkins dalam Alwi (1992: 89) menyatakan bahwa istilah 'pengetahuan' diartikan sebagai 'kekurangtahuan' (lack of knowledge), sedangkan Coates dalam Alwi (1983:89) mengartikannya sebagai 'kekurangyakinan' (lack of confidence). Perkins menyimpulkan bahwa yang di persoalkan dalam modalitas epistemik adalah sikap pembicara yang didasari oleh kaidah rasional atau daya nalar pembicara mengenai keyakinan atau kekurangyakinannya terhadap kebenaran proposisi. Modalitas epistemik mencakup 'kemungkinan', 'keteramalan', 'keharusan', atau 'kepastian'. (Alwi, 1992:91). 
Coates (1983:18) memberikan contoh sebagai berikut:

Paul must be in Liverpool by now.

'Paul pasti berada di Liverpool sekarang'

Contoh yang dikemukakannya, bahwa must merupakan modalitas epistemik yang bermakna 'kemungkinan'. Asumsi pembicara pada contoh di atas, menurut Coates, dapat diparafrasa menjadi: 'Saya berasumsi bahwa berdasarkan pukul berapa dia pergi, pukul berapa sekarang, dan bagaimana keadaan sarana angkutan umum, Paul sekarang berada di Liverpool.

Dikemukakannya bahwa asumsi pembicara mengekplisitkan fakta bahwa makna epistemik must melibatkan pembicara dalam hal pengambilan kesimpulan logis meskipun fakta yang mendasari kesimpulan itu sering tidak dinyatakan. Pendapat ini sejalan dengan pandangan Perkins (1983) mengenai kaidah rasional atau daya nalar pembicara yang menjadi tolak ukur modalitas epistemik. Terlibatnya pembicara dalam memberikan penilaian terhadap kebenaran proposisi menyebabkan modalitas epistemik berciri subjektif.

Huddleston (2002:178) mengemukakan bahwa 'Deontic' is derived from Greek for 'binding' so that here it is a matter of improving obligation or prohibition, granting permission, and the like. The person, authority, convention, or whatever from the obligation, etc, is understood to emanate we refer to as the deontic source". Maksudnya yaitu 'Deontik' berasal dari bahasa Yunani yang bermakna 'mengikat' berupa perintah atau larangan, pemberian izin, dan sejenisnya. Seseorang, yang memiliki otoritas, konvensi, atau apapun berupa perintah dan lain-lain, dipahami sebagai sumber deontik.

Alwi (1992:163) berpandangan bahwa modalitas dinamik merupakan sikap pembicara terhadap aktualisasi peristiwa yang didasarkan pada perikeadaan (circumstances) yang lebih bersifat empiris sehingga, menurut Perkins (1983:10-11), yang dijadikan sebagai tolak ukur oleh pembicara adalah hukum alam (laws of nature). Modalitas dinamik bersifat objektif karena keberlangsungan peristiwa tidak tergantung kepada pembicara, tetapi pada subjek yang berperan sebagai pelaku dalam hal ini terlihat pada makna kemampuan (ability).

Modalitas ganda merujuk ke istilah Huddleston (2002:179) disebut dengan modal harmony, yaitu kesesuaian modal. Hal ini berarti terdapat kombinasi antara modal leksikal dan unsur gramatikal dalam sebuah kalimat. Bentuk yang paling umum dalam modal harmony dapat ditemukan dalam kombinasi verba bantu modal dan adverb (kata keterangan). Secara semantis, kombinasi modal leksikal dan gramatikal mengungkapkan makna modal tunggal.

Contoh: The meeting must surely be over by now.

'Pertemuan ini pastinya sudah selesai sekarang'

Contoh diatas menunjukkan bahwa kalimat tersebut terdapat kombinasi antara verba bantu modal yaitu must dan modal leksikal berupa kata keterangan yaitu surely.

Disisi lain, secara geografis menurut Di Paolo (1989:234), Boertien, (1986:300), Brandstetter, (2003:123) dan Hasty (2011:247) terdapat fenomena mengenai modalitas ganda serta menemukan lebih dari 40 juta penutur bahasa Inggris di Amerika terutama di negara bagian Texas, Pennsylvania selatan, New Jersey dan New York yang menggunakan modalitas ganda. Modalitas ganda tersebut terdiri atas kombinasi antara verba bantu modal dan verba bantu modal lainnya dalam kalimat. Berdasarkan jumlah populasinya, penutur tidak hanya berasal dari penduduk asli 
sekitar tetapi juga imigran Afrika - Amerika, Meksiko - Amerika dan Puerto Rica - Amerika. Dalam hal ini biasanya modalitas ganda tersebut digunakan dalam bentuk percakapan.

\section{RUMUSAN MASALAH}

Adapun permasalahan yang dibahas dalam kajian ini dapat dirumuskan sebagai berikut: Jenis makna modalitas apa yang terdapat dalam modalitas ganda dalam bahasa Inggris?

\section{METODE PENELITIAN}

Metode merupakan cara mendekati, mengamati, menjelaskan, dan menganalisis suatu fenomena atau data (Wahya, 2005:25). Dalam kajian ini, metode yang digunakan adalah metode penelitian deskriptif. Metode deskriptif digunakan untuk mendeskripsikan data apa adanya dan menjelaskan gejala-gejala yang ada pada data tersebut. Dengan demikian, dapat dilihat suatu gambaran yang sistematis, faktual, dan akurat tentang data yang dikaji. Hal ini sesuai dengan apa yang dikemukakan oleh Djajasudarma (1993:16), bahwa metode deskriptif digunakan untuk memerikan ciri-ciri, sifat-sifat, serta gambaran data melalui pemilahan data yang dilakukan pada tahap pemilahan data setelah data terkumpul. Dengan demikian peneliti senantiasa mengacu pada data itu sendiri dan tidak berpandangan bahwa sesuatu itu memang demikian adanya.

Data yang digunakan dalam penelitian ini adalah data dalam bahasa Inggris ragam tulis. Data bahasa Inggris ragam tulis digunakan dengan alasan bahwa bahasa ragam tulis merupakan manifestasi dari bahasa ragam lisan yang biasanya digunakan sehari-hari. Dalam hal pengumpulan data, tahapan atau langkah-langkah yang diambil sesuai dengan permasalahan penelitian, yaitu sebagai berikut:

1. Mencari bentuk-bentuk pengungkapan yang menyatakan modalitas ganda beserta maknanya dalam bahasa Inggris dari sumber data yang akan digunakan dalam penelitian ini;

2. Menandai dan menyalin semua data yang ditemukan dan mencari padanannya dalam teks terjemahan yang diperoleh dari sumber data;

3. Mengumpulkan data dengan sistem kartu, memberinya nomor dan kode, lalu mengklasifikasikannya berdasarkan kode-kode tersebut;

4. Memilah data, yaitu bentuk-bentuk pengungkapan modalitas ganda dalam bahasa Inggris dan padanannnya dalam bahasa Indonesia, berdasarkan klasifikasi data baik secara sintaktis maupun semantis.

Metode kajian atau pemerian bagaimana data dianalisis berdasarkan pendekatan tertentu yang digunakan dalam penelitian ini adalah dua metode yang digunakakan yaitu metode padan dan distribusional. Metode padan digunakan apabila alat penentunya adalah unsur luar bahasa, misalnya referensi, penutur, bahasa atau ragam bahasa lain, peserta bicara, atau tulisan. Metode distribusional digunakan jika alat penentunya adalah unsur yang terkandung dalam bahasa itu sendiri, yakni bahasa yang sedang diteliti (Djajasudarma, 1993; dan Sudaryanto, 1994).

Dengan menggunakan metode-metode tersebut, data ditelaah dengan mengungkapkan aspek sintaktis sekaligus semantisnya. Berdasarkan metode yang digunakan, dalam kajian dan interpretasi data penelitian ini digunakan berbagai teknik, yaitu teknik lesap (deletion), teknik sulih (substitution), dan teknik pemindahan. Data yang digunakan dalam penelitian ini dipilih dalam bentuk ragam Bahasa tulis. Ragam bahasa tulis dipilih sebagai sumber data dengan pertimbangan bahwa ragam tulis memperlihatkan ciri yang lebih konsisten daripada ragam lisan, baik dalam penggunaan struktur kalimat maupun pilihan kata (Alwi, 1992:25). Data yang dikumpulkan dalam 
kajian ini adalah bentuk modalitas ganda dalam bahasa Inggris dan padanannya dalam bahasa Indonesia.

Adapun sumber data yang digunakan dalam penelitian ini yaitu dari COCA (Corpus of Contemporary American English).

\section{HASIL DAN PEMBAHASAN}

Berdasarkan penulusuran data dari COCA (Corpus of Contemporary American English) ditemukan sebanyak 5 data yang mempunyai modalitas ganda dengan verba bantu modal have to dikombinasikan dengan adverb (kata keterangan) seperti surely yang terdapat dalam data 1 dan certainly yang terdapat dalam data 2 sampai 5.

1.Well, we have to surely say that the big bang occurred 14 billion years ago. (www.coca.edu.com)

'Nah, kita seharusnya memang mengatakan bahwa big bang terjadi 14 miliar tahun yang lalu'

2. I think that we have to certainly continue to be engaged. I believe that the United Nations pulled out totally. I would hope that they would be in a surrounding country where negotiations and diplomatic talks can continue to go on._(www.coca.edu.com)

'Saya pikir kita memang seharusnya bersama sama. Saya percaya bahwa Perserikatan BangsaBangsa secara total mencabut. Saya berharap bahwa mereka akan berada di negara sekitar di mana negosiasi dan pembicaraan diplomatik dapat terus berlanjut'

3. We have to certainly assume so. In fact, because there's a lot of pressure coming from lay groups all over the world, there was always a sense that this was a great, great pope but not always so in tune with the realities of Catholics out in the real world. (www.coca.edu.com)

'Kita memang seharusnya berasumsi demikian. kenyataannya, karena ada banyak tekanan yang datang dari kelompok awam di seluruh dunia, selalu ada perasaan bahwa ini adalah paus yang hebat dan hebat, tapi tidak selalu selaras dengan realitas umat Katolik di dunia nyata'

4. We have to certainly assume so. In fact, because there's a lot of pressure coming from lay groups all over the world, there was always a sense that this was a great, great pope but not always so in tune with the realities of Catholics out in the real world. (www.coca.edu.com)

'Kita memang seharusnya berasumsi demikian. kenyataannya, karena ada banyak tekanan yang datang dari kelompok awam di seluruh dunia, selalu ada perasaan bahwa ini adalah paus yang hebat dan hebat, tapi tidak selalu selaras dengan realitas umat Katolik di dunia nyata'

5. I trust in the professionalism of our military to do their jobs and do it well, but we have to certainly focus more on making sure that the military does a better job with sexual assault. (www.coca.edu.com)

'Saya percaya pada profesionalisme militer kita untuk melakukan pekerjaan mereka dan melakukannya dengan baik, tapi kita memang seharusnya lebih fokus untuk memastikan bahwa militer melakukan pekerjaan yang lebih baik dengan kekerasan seksual' 
Secara sintaksis, Data 1.2.3.4.5 menunjukkan terdapat kombinasi antara verba bantu modal yaitu have to dan modal leksikal berupa kata keterangan yaitu surely, certainly serta merupakan pengungkap kesimpulan logis (logical necessity) dan termasuk ke dalam modalitas epistemik yang memiliki makna kepastian yang subjektif. Pengungkapan modalitas epistemik ditunjukkan oleh pemunculan kepastian penutur yang melibatkan pengetahuannya atau keyakinannnya. Dalam hal ini terlihat bahwa penutur telah menarik suatu kesimpulan dari hal-hal yang telah diketahui atau diamati sebelumnya. Padanan have to dalam bahasa Indonesia dalam konteks kalimat ini menjadi 'seharusnya' dan termasuk ke dalam pengungkap ekstraklausal, dimana terdapat kecenderungan penutur untuk menyatakan bahwa keharusan yang diungkapkan tersebut berasal dari dirinya sendiri, bukan dari orang lain. Selain itu, 'seharusnya' cenderung digunakan sehubungan dengan sesuatu yang telah terjadi.

\section{KESIMPULAN Dan SARAN}

\section{KESIMPULAN}

Hasil penelitian menunjukkan terdapat kombinasi antara verba bantu modal yaitu have to dan modal leksikal berupa kata keterangan yaitu surely, certainly yang merupakan pengungkap kesimpulan logis (logical necessity) dan termasuk ke dalam modalitas epistemik yang memiliki makna kepastian yang subjektif. Pengungkapan modalitas epistemik ditunjukkan oleh pemunculan kepastian penutur yang melibatkan pengetahuannya atau keyakinannnya. Dalam hal ini terlihat bahwa penutur telah menarik suatu kesimpulan dari hal-hal yang telah diketahui atau diamati sebelumnya. Padanan have to dalam bahasa Indonesia menjadi 'seharusnya' dan termasuk ke dalam pengungkap ekstraklausal, dimana terdapat kecenderungan penutur untuk menyatakan bahwa keharusan yang diungkapkan tersebut berasal dari dirinya sendiri, bukan dari orang lain.

\section{SARAN}

Penelitian ini dapat dipandang sebagai upaya memperkuat, melengkapi, dan mengembangkan serta mengkritik teori yang sudah ada. Hasil yang dicapai merupakan sumbangan bagi perkembangan linguistik, khususnya yang menyangkut modalitas dalam bahasa Inggris, baik secara sintaksis maupun semantis. Modalitas merupakan suatu bentuk bahasa yang bersifat universal serta memiliki karakteristik tersendiri yang mencakup sejumlah kelas kata. Penelitian ini mempunyai keterbatasan dalam mengungkap masalah pada modalitas ganda. Dalam hal ini, peneliti menyarankan pada peneliti berikutnya untuk lebih banyak mengkaji lebih lanjut mengenai struktur frasa verba berpemarkah modalitas keharusan dalam bahasa Inggris.

\section{UCAPAN TERIMA KASIH}

Ucapan terima kasih kepada semua pihak yang telah berkontribusi dalam penelitian ini. Penelitian ini merupakan Penelitian Dosen Pemula yang didanai oleh Direktorat Riset dan Pengabdian Masyarakat, Direktorat Jenderal Penguatan Riset dan Pengembangan, Kementerian Riset, Teknologi, dan Pendidikan Tinggi sesuai dengan Kontrak Penelitian Nomor: 110/SP2H/PPM/DRPM/2019, tanggal 8 Maret 2019.

\section{REFERENSI}

Alwi, H. (1992). Modalitas dalam Bahasa Indonesia. Yogyakarta: Penerbit Kanisius Badudu, J. S. (2003). Metode penelitian linguistik dalam uvula. Jurnal Sastra 2(1).

Boertien, H.S. (1986). Constituent structure of double modals in language variety in the south: perspectives in black and white. M. Montgomery \& G.Bailey (Eds) pp. 294-318. University of Alabama Press. 
Brandstetter, C.(2003). A study in syntactic variation: Double modal constructions. Georgetown University.

Chaer, A.(1992) linguistik umum. Jakarta: PT. Rineka Cipta.

Coates, J.(1983). The semantics of modal auxiliaries. London: Croom Helm.

Coca (Corpus of Contemporary American English). www.coca.edu.com

Di Paolo, M.(1989). A study of double modals in Texas English. Doctoral Dissertation, University of Texas at Austin.

Djajasudarma, T. F. (1993).Metode linguistik: Ancangan metode penelitian dan kajian. Bandung: PT. Eresco.

Hasty, J. D. (2011). We might should oughta take a second look at this: A syntactic re-analysis of double modals in Southern United States English. Michigan State University.

Huddleston, R.D., \& Pullum, G.K. (2002). The cambridge grammar of the english language. Cambridge, UK: Cambridge University Press.

Hurford, J. R \& Heasley, B.(1983). Semantics: A coursebook. Cambridge. Cambridge University Press.

Kempson, R. M.(1977). Semantic Theory. Cambridge: Cambridge University Press.

Keraf, G..(1982). Tata bahasa indonesia. cetakan kesepuluh, cetakan pertama 1970. Ende: Penerbit Nusa Indah.

Kridalaksana, H. (2001). Kamus Linguistik. Jakarta: PT Gramedia Pustaka Utama.

Lyons, J. (1981). Language, meaning and context. Cambridge University Press.

Miller, J.(1982). Semantics and syntax: Parallels and connections. Cambridge: Cambridge University Press.

Nugraha, D. N. S. (2016). Verb Go Combinations in Perspective English Linguistics and Culture. $\begin{array}{llllll}\text { Journal } & \text { Sampurasun, } & 2(1) & 101 & - & 108 .\end{array}$ http://dx.doi.org/10.23969/sampurasun.v2i01.115.

Nugraha, D. N. S., \& Sobarna, C., Mahdi, S., \& Darmayanti, N. (2018). The mode of 'must' in the modality of necessity in english and its equivalents in indonesia: a syntactic and semantic $\begin{array}{llll}\text { analysis. Journal } & \text { 82-92. }\end{array}$ http://dx.doi.org/10.23969/sampurasun.v4i02.856.

O’Grady, W. ( 1997). An introduction to contemporary linguistics. London: Longman.

Palmer, F.R.(1979). Modality and the english modals.London: Longman.

Perkins, Michael R. 1983. Modal Expressions in English. Norwood: Ablex Publishing Corporation.

Quirk, R.,Sidney, G., Geoffrey L, \& Jan S.(1985). A comprehensive grammar of the english language. London: Longman.

Radford, A.(1999). Transformational grammar. Cambridge: Cambridge University Press.

Saeed, J.I. (2003). Semantics. UK: Blackwell Publishing Ltd.

Sudaryanto. (1994).Metode dan aneka teknik analisis bahasa: Pengantar penelitian wahana kebudayaan secara linguistis. Yogyakarta: Duta Wacana University Press.

Wahya.(2005.) Inovasi dan difusi-geografis leksikal bahasa melayu dan bahasa sunda di perbatasan bogor-bekasi: Kajian geolinguistik. Program Pascasarjana Universitas Padjadjaran. 